The Power of Life 



\section{The Power of Life}

AGAMBEN AND THE COMING POLITICS

(To Imagine a Form of Life, II)

David Kishik 
Stanford University Press

Stanford, California

(C) 2012 by the Board of Trustees of the Leland Stanford Junior University.

All rights reserved.

No part of this book may be reproduced or transmitted in any form or by any means, electronic or mechanical, including photocopying and recording, or in any information storage or retrieval system without the prior written permission of Stanford University Press.

Printed in the United States of America on acid-free, archival-quality paper

Library of Congress Cataloging-in-Publication Data

Kishik, David, author.

The power of life : Agamben and the coming politics (To imagine a form of life, II) / David Kishik.

pages $\mathrm{cm}$

Includes bibliographical references and index.

ISBN 978-o-8047-7229-7 (cloth : alk. paper) — ISBN 978-0-8047-7230-3 (pbk. : alk. paper)

1. Agamben, Giorgio, 1942- 2. Political science-Philosophy. 3. Philosophy, Modern. I. Title.

B3611. A44K57 2012

195-dc22

2011013706

Typeset by Bruce Lundquist in 9/15 Palatino with Walbaum display 